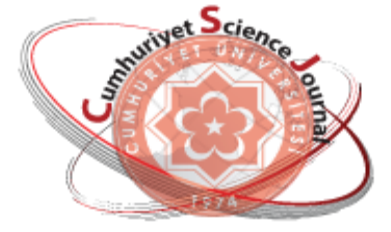

e-ISSN: 2587-246X

ISSN: $2587-2680$

\section{Cumburiys ot Seionee Journal}

CSy

Cumhuriyet Sci. J., Vol.40-3 (2019) 776-783

\title{
Assesment of outdoor radioactivity and health risk in Adıyaman Province of Turkey
}

\author{
Muhammet KARATASTLI \\ Beykent University, Faculty of Engineering and Architecture, Department of Electronics and Communication
}

Engineering, İstanbul, TURKEY

Received: 09.03.2019; Accepted: 25.08.2019

http://dx.doi.org/10.17776/csj.537809

\begin{abstract}
This study was conducted to determine the outdoor absorbed gamma dose levels in and around Adiyaman province in the southeast of Turkey. Measurements were performed using a portable plastic scintillator at 94 different points (Eberline Smart Portable (ESP-2) model). Three readings were made for each measurement and the mean of these three values were determined and the gamma dose values were determined for each measurement region. External gamma irradiation velocities were measured between 63.5 $(\mathrm{nGy} / \mathrm{h})$ and $380.2(\mathrm{nGy} / \mathrm{h})$ levels in Adiyaman and surrounding areas and the mean value was calculated as $144.3(\mathrm{nGy} / \mathrm{h})$. This value corresponds to the average effective dose equivalent of $177 \mu \mathrm{Sv}$ per year. The lifetime averages of cancer risk values for ICRP 103, BEIR VII and ICRP 60 were found to be $0.071,0.079$ and 0.089 , respectively. The results obtained with the results of similar studies in other provinces in Turkey and compared with the world average
\end{abstract}

Keywords:Cancer risk, gamma dose, annual effective dose, Adiyaman Province.

\section{Adıyaman İlinde Dış Mekan Radyoaktivitesi ve Sağlık Risklerinin Değerlendirilmesi}

Özet. Bu çalışma Türkiye'nin güneydoğusunda bulunan Adıyaman ili ve çevresinde açık havada soğurulan gama radyasyon doz seviyesini belirlemek için yapılmıştır. Ölçümler önceden belirlenmiş 94 farklı noktada (Eberline Smart Portable (ESP-2) model) portatif bir plastik sintilatör kullanılarak yapıldı. Her ölçüm için üçer okuma yapılmış ve bu üç değerin ortalaması alınarak her bir ölçüm bölgesi için gama doz değerleri belirlendi. Adıyaman ve çevresinde dış gama dozu kullanılarak, dış gama ışınlanma hızları $63.5(\mathrm{nGy} / \mathrm{h})$ ile $380.2(\mathrm{nGy} / \mathrm{h})$ değerleri arasında ölçüldü ve ortalama değer $144.3(\mathrm{nGy} / \mathrm{h})$ olarak hesaplandı. Bu değer yıllık etkin doz eşdeğeri $177 \mu \mathrm{Sv}$ değerinde etkin doz ortalamasına karşılık gelmektedir. Adıyaman ve çevresinde yaşam boyu kanser risk değerleri ICRP 103, BEIR VII ve ICRP 60 için yüzdelik ortalamaları sırasıyla sırasıyla $0,071,0,079$ ve 0,089 olarak bulundu. Elde edilen sonuçlarla Türkiye'de diğer illerde yapılan benzer çalışmaların sonuçları ve dünya ortalamaları ile karşılaştırılmıştır.

AnahtarKelimeler:Kanser riski, gama doz., y1llık etkin doz, Adıyaman.

\section{INTRODUCTION}

Although most people think that radiation is released only from man-made devices and structures (medicine, industry, research, nuclear power plants, agriculture and animal husbandry), they emit radiation to the environment in which we live in very long-lived radioactive elements that have taken place in nature since the formation of the 
universe. Natural radiation is the main source of radiation that people are exposed to in their environment. While living things are under the influence of a dose of $85 \%$ from natural radiation sources, they are under $15 \%$ of artificial radiation sources $[1,2]$.

The major contribution to natural radiation is the naturally occurring U-238, Th-232 and their degradation products, Ra-226, Rn-222 and U-235, which are derived from radioactive elements such as K-40 [3]. The mass activity concentration is the radiation intensity corresponding to the absorbed dose in the air at a height of $1 \mathrm{~m}$. Therefore, the radiation dose measured in the air is closely related to the radio-core concentrations in the soil $[4,5]$.

The contribution of cosmic temperatures to natural radiation varies with height and is taken as constant at certain latitude values as they rise up from sea level $[6,7]$.

Nuclear weapons experiments conducted on the earth from 1945 to the present day and the Chernobyl nuclear accident that occurred in 1986 caused the spread of radioactive elements to the environment. However, these radiations can also be called ground level radiation, and the geological and geographic, geographic and geographic region, so the soil and rocks with the geographic height, the level of the level of the level of radiation affect $[9,10]$.

In order to determine whether the area inhabited in terms of natural radiation is healthy or not, it is necessary to determine the concentrations of radio-nuclei that constitute natural sources of radiation and the effect of radiation on human beings and to determine the effect of radiation on biological systems. Therefore, studies have been conducted to evaluate the doses and types of radiation caused by environmental factors, as well as the risks it may pose to human health [2].

In this study, determination of the dose level of gamma radiation absorbed in the outdoor in and around Adiyaman province is important in terms of determining the rate of exposure of the natural radiation to the radiation caused by various nuclear applications. The results presented in this study were compared with the results of Turkey's and the world average of similar studies conducted in different regions. The results of the study may serve as a reference for future assessments.

\section{MATERIALS AND METHODS}

\subsection{Geology of the survey area}

Adiyaman, which has a surface area of $7614 \mathrm{~km}^{2}$, is located between the northern latitudes of the $37^{\circ} 25^{\prime}$ $38^{\circ} 10^{\prime}$ and the eastern longitudes of the $37^{\circ} 27^{\prime}-39^{\circ} 15^{\prime}$. The land structure of the province has a rugged view that descends from north to south. Adiyaman and its surroundings are shown in Figure 1.

On the lands of Adiyaman, one of the oldest settlements in the world, findings about all phases of human history have been obtained. Adiyaman, the 8th wonder of the world known as the Nemrut Mountain works, the ruins of the Commagene civilization, the 4th largest dam in the world, the Atatürk Dam, the Çamgazi dam, the winter camp organization, the world championship is a city with the world's first [11].

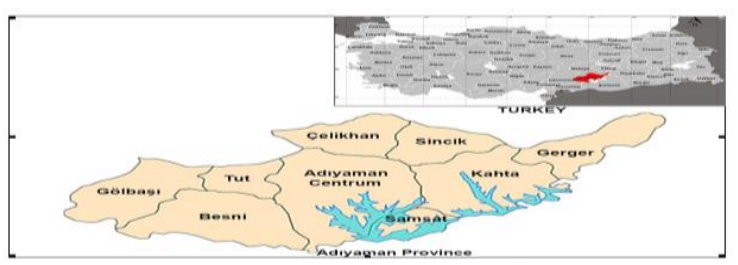


Figure 1. Map of the study area; Adiyaman province, Turkey [12].

The north of Adiyaman is mountainous and the south is ovalık. The plain runs from the south to the banks of the EuphratesRiver and the Atatürk Dam. A few kilometers north of the province and the central district, the mountainous areas begin to rise northward. These mountains, which are part of the southeastern Taurus, extend in the east-west direction. In the mountainous areas to the north, which make up more than one third of the face, the highland climate prevails [13].

There are several units of magmatic, metamorphic and sedimentary rocks formed in the geological time period from Mesozoic to the present day. Mesozoic units are the oldest of these geological units. Eocene limestones anticline structures are exposed in the eroded or faulted areas of Plio-Quaternary deposits. Apart from this, the base area consists entirely of Plio-Quaternary fillings. The youngest formations are the Quaternary alluviums in the valley floor and slab systems [14].

The number of stations with the altitude and catchment area of each district were given in Table 1 . The geographic coordinates of the stations were determined by using GPS devices.

\subsection{Gamma Scintillation Detector}

In this study, a device with Eberline Smart Portable (ESP-2) model, portable microcomputer and SPA-6 model plastic scintillation detector connected to the end was used for determination of gamma radiation levels. The Eberline Smart Portable (ESP-2) is a portable radiation inspection instrument that can be mounted with radiation detectors, a microcomputer-based and data-recording instrument. This instrument is designed for use in routine radiation examinations and allows multiple readings and can be subsequently connected to a computer and printer. ESP -2 is designed as an interface for the user, it has seven multifunction on / off buttons and a liquid crystal display (LCD). The data is given either as scientific or moving point recording and in selectable units of measurement. In addition, the instrument consists of an external headset and speaker system for use in high radiation areas $[15,16]$.

Table 1. Distribution of stations in the research region of Adiyaman

\begin{tabular}{lllllll}
\hline District & Latitude $(\mathrm{N})$ & Longitude $(\mathrm{E})$ & Altitude $(\mathrm{m})$ & $\begin{array}{c}\text { Catchment area } \\
\left(\mathrm{km}^{2}\right)\end{array}$ & $\begin{array}{c}\text { Population } \\
(2017)\end{array}$ & $\begin{array}{c}\text { Number } \\
\text { Stations }\end{array}$ \\
\hline AdiyamanCenter & 37.759722 & 38.259722 & 669 & 1702 & 301589 & 33 \\
Gölbaş1 & 37.7768518 & 37.6374277 & 867 & 784 & 49059 & 8 \\
Kahta & 37.7750854 & 38.6139386 & 750 & 1490 & 120859 & 14 \\
Besni & 37.6890364 & 37.8545142 & 930 & 1330 & 75499 & 13 \\
Samsat & 37.5762285 & 38.4677502 & 610 & 338 & 7530 & 6 \\
Tut & 37.7886992 & 37.9097588 & 1050 & 350 & 9936 & 6 \\
Çelikhan & 38.0255984 & 38.2366530 & 1388 & 584 & 15326 & 4 \\
Gerger & 38.0280715 & 39.0341811 & 750 & 702 & 18244 & 6 \\
\hline Sincik & 38.0364507 & 38.6125706 & 1325 & 364 & 17034 & 4 \\
\hline
\end{tabular}




\section{RESULTS AND DISCUSSION}

In order to determine the dose level of gamma radiation absorbed outdoors in 94 different regions in and around Adiyaman, the height of gonad (reproductive organs) in humans is approximately $1 \mathrm{~m}$ above the ground. Measurements were taken with Eberline portable detector. Three different readings were made at a radius of 5 meters while the measurements were taken in each region and the mean of these three values were determined and gamma dose values were determined for each measurement region.

The results of the measurements of the external gamma dose obtained in the open air at a height of 1 meter from the ground in the 94 different regions of Adiyaman and around it are given in Table 2. During the determination of the gamma dose values, three readings were made at each measurement site. Gamma dose values were determined for each measurement point by taking the average of the three values. The results include both cosmic and terrestrial radionuclides.

While the contribution of terrestrial gamma radiation in the air is very large, space-based cosmic rays also contribute to the ratio. Measurements carried out at a height of $1 \mathrm{~m}$ from the ground are important in terms of measurement in the outdoors, in the level of reproductive organs in humans. The results of gamma irradiation rates were obtained in $\mu \mathrm{R} / \mathrm{h}$ in the measurements performed for one minute in the open air. As can be seen in Table 2, the results obtained in the measurements were converted to $\mathrm{nGy} / \mathrm{h}$ elde, which was the absorbed dose rate using a conversion factor (8.7 $\mathrm{nGy} / \mu \mathrm{R})$ from the definition of Rontgen [17].

Table 2. Gama exposure dose rate and absorbed dose rate for each districts of the Adiyaman

\begin{tabular}{|c|c|c|c|c|c|c|}
\hline \multirow[b]{2}{*}{ District } & \multicolumn{3}{|c|}{$\begin{array}{c}\text { GEDR (Gamma Exposure Dose Rate) } \\
(\mu \mathrm{R} / \mathrm{h})\end{array}$} & \multicolumn{3}{|c|}{$\begin{array}{c}\text { ADRA (Absorbed Dose Rate in Air) } \\
(\mathrm{nGy} / \mathrm{h})\end{array}$} \\
\hline & Minimum & Maximum & Mean & Minimum & Maximum & Mean \\
\hline AdıyamanCenter & 10.8 & 40.3 & 15.5 & 94 & 350.6 & 134.4 \\
\hline Gölbaş1 & 7.3 & 43.7 & 19.7 & 63.5 & 380.2 & 171 \\
\hline Kahta & 9.2 & 19.6 & 13.7 & 80 & 170 & 118.8 \\
\hline Besni & 13.1 & 34.3 & 18.7 & 114 & 298.4 & 163 \\
\hline Samsat & 13.2 & 22.3 & 16.4 & 114.8 & 194 & 143 \\
\hline Tut & 11.4 & 24.5 & 19.3 & 99.2 & 213.2 & 167.9 \\
\hline Çelikhan & 21.2 & 29.5 & 24.7 & 184.4 & 256.7 & 214.7 \\
\hline Gerger & 7.8 & 17.6 & 13.5 & 67.9 & 153.1 & 117.2 \\
\hline Sincik & 12.3 & 18.2 & 15.9 & 107 & 158.3 & 138.1 \\
\hline Region & 7.3 & 43.7 & 16.6 & 63.5 & 380.2 & 144.3 \\
\hline
\end{tabular}

By using a dose ratio of the gamma radiation absorbed in the air, the annual effective dose equivalent (AEDE) may be the amount of exposure to which the human is exposed to radiation for one year. Using the equation below, the annual effective dose equivalent is calculated $[18,19]$.

\section{$\mathrm{AEDE}=\mathrm{ADRA} * \mathrm{DCF} * \mathrm{OF} * \mathrm{~T}$}

Here, the annual effective dose equivalent of AEDE, ADRA is the ratio of gamma radiation dose absorbed in the air; The environmental gamma dose conversion factor was determined to be $0.7 \mathrm{~Sv} / \mathrm{Gy}$ to convert the absorbed dose ratio to the annual effective dose equivalent. In addition, when a person spent $20 \%$ of the time he was exposed to rays during a year $(8760 \mathrm{~h} / \mathrm{y})$ he spent outside the home in open spaces, a coefficient of 0.2 was used as out-ofhome occupation factor. In addition, lifetime risk of cancer ELCR Denk. (2)[20,22]. 
Here, the AEDE is the annual effective dose equivalent, the average life expectancy of DL (average 70 years), and the risk factor for RF, and for stochastic effects, ICRP risk factors for lethal cancer in the whole population, respectively (1/Sv), RF ICRP 103, BEIR VII [23] (NRC, 2006) and for ICRP 60, 0.057, 0.064 and 0.072 are used [24].

Table 3 shows the AEDE and the ELCR values of people who have been exposed for one year in Adiyaman and its surroundings, calculated by Equation1 and Equation2, and environmental gamma radiation for one year.

Table3. The average annual effective dose values and lifetime cancer risk

\begin{tabular}{|c|c|c|c|c|}
\hline \multirow{3}{*}{ District } & \multirow{3}{*}{$\begin{array}{l}\text { AEDE } \\
(\mu \mathrm{Sv} / \mathrm{y}\end{array}$} & \multicolumn{3}{|c|}{ Lifetime cancer risk \% } \\
\hline & & ICRP 103 & BEIR VII & ICRP 60 \\
\hline & & & & \\
\hline AdıyamanCenter & 164.8 & 0.066 & 0.074 & 0.083 \\
\hline Gölbaş1 & 209.7 & 0.084 & 0.094 & 0.106 \\
\hline Kahta & 145.7 & 0.058 & 0.065 & 0.073 \\
\hline Besni & 199.9 & 0.080 & 0.090 & 0.101 \\
\hline Samsat & 175.4 & 0.070 & 0.079 & 0.088 \\
\hline Tut & 205.9 & 0.082 & 0.092 & 0.104 \\
\hline Çelikhan & 263.3 & 0.105 & 0.118 & 0.133 \\
\hline Gerger & 143.7 & 0.057 & 0.064 & 0.072 \\
\hline Sincik & 169.4 & 0.068 & 0.076 & 0.085 \\
\hline Region & 177.0 & 0.071 & 0.079 & 0.089 \\
\hline
\end{tabular}

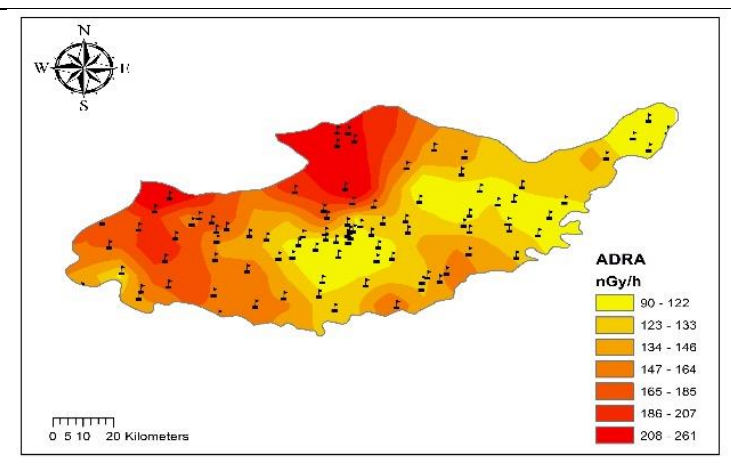

Figure 2ADRA in Adiyaman

In addition, the absorbed gamma dose map obtained from the measurements for Adiyaman and its surroundings was drawn. Figure 2 shows the general distribution of the absorbed gamma dose rate across the province in the form of an isodose map. The dark regions represent areas with high abundance of absorbed gamma dose in Adiyaman and its vicinity.The arithmetic mean of the gamma dose measurements performed in 94 different regions in and around Adiyaman province was calculated as $144.3 \mathrm{nGy} / \mathrm{s}$. The mean value of the annual effective dose equivalent calculated using the external gamma dose was found to be $177 \mu \mathrm{Sv} / \mathrm{y}$. This value is greater than the value of 73.6 $\mu \mathrm{Sv} / \mathrm{y}$ [25], which is determined as the world average of the annual effective dose equivalent, as shown in Table 4. Also it found was greater than the average annual effective dose equivalent in other provinces outside the studies 
carried out in the province of Adiyaman in the study average annual effective dose equivalent Balikesir province in Turkey.

Table 4. Absorbed dose rate in air (94 readings) and the corresponding annual effective doses for the districts of Adiyaman and comparison with literature

\begin{tabular}{|c|c|c|}
\hline & $\begin{array}{c}\text { ADRA } \\
\text { (Absorbed Dose } \\
\text { Rate) } \\
(\text { nGy/h) }\end{array}$ & $\begin{array}{c}\text { AEDE } \\
\text { (Annual effective dose) } \\
(\mu \mathrm{Sv} / \mathrm{y})\end{array}$ \\
\hline Hatay [2]. & 61.9 & 75.9 \\
\hline Çankırı [26]. & 69.6 & 87.7 \\
\hline Trabzon [27]. & 59 & 72.4 \\
\hline Tekirdağ [28]. & 43.85 & 53.77 \\
\hline Çanakkale [29]. & 66.4 & 81.4 \\
\hline Şanlıurfa[10]. & 60.9 & 74.7 \\
\hline Kastamonu [30]. & 54.81 & 67.21 \\
\hline İstanbul [31]. & 65 & 79.7 \\
\hline Balıkesir [32]. & 127 & 155.8 \\
\hline Yalova [33]. & 84 & 103 \\
\hline Kırklareli [22]. & 118 & 144.7 \\
\hline Kahramanmaraş [15]. & 64.8 & 79.5 \\
\hline Worldwide [25]. & 60 & 70 \\
\hline
\end{tabular}

\section{CONCLUSION}

The arithmetic average of gamma dose measurements in Adryaman and its vicinity is less than $1 \mathrm{mSv} / \mathrm{y}$, as determined by the ICRP as the limit value of the annual effective dose equivalent of $144.3 \mathrm{nGy} / \mathrm{h}$ [34]. The lifetime averages of cancer risk values for ICRP 103, BEIR VII and ICRP 60 in Adryaman and its vicinity were found to be $0.071,0.079$ and 0.089 , respectively.

The issue of radiation has become one of the most controversial phenomena in the world after the unfortunate nuclear reactor accidents, and people's sensitivities to this issue are increasing day by day. In parallel with this awareness, people's demand for information on radiation is increasing. Therefore, it is extremely important for people to be informed about the natural radiation that they will be exposed to stay in according to their geographic and geological characteristics. Therefore, this study, environmental gamma dose measurements in Adiyaman and its districts can be used as baseline data for future studies and a reference for future evaluations 
can be made. It will also be very useful in terms of radiation monitoring in the event of any nuclear accident in the future and in the evaluation of radiological risks to human health.

\section{REFERENCES}

[1] UNSCEAR, 2008. United Nations Scientific Committee on the Effects of Atomic Radiation, United Nations Publication, New York, USA.

[2] Karataşl1, M. 2018. Hatay İli ve çevresinde gama radyasyon ölçümü, Afyon Kocatepe Üniversitesi Fen ve Mühendislik Bilimleri Dergisi, 18, 3,780-785.

[3] Smith, J. and Beresford, N.A. 2005. Chernobyl, Catastrophe and Consequences. Springer, 310, New York.

[4] Beck, H.L, 1982. The Natural Radiation Environment II. USERDA Conf.-720805-P2, The Physics of Environmental Gamma Radiation Fields, 101-104.

[5] NCRP, Report No. 50, 1977. National Council on Radiation Protection and Measurements, (1977), Environmental Radiation Measurement, ISBN. 0- 913392-32-4.

[6] Eisenbud, M. 1987. Environmental Radioactivity, Third Edition, ISBN. 0-12-235153, Academic Pres, Inc., London.

[7] Karataşl1, M., and Özer, T. 2017. Investigation of Radiation Activity Growing Peanuts in Osmaniye, Süleyman Demirel University Journal of Natural and Applied Sciences, 21, 3, 1017-1023.

[8] Karataşl1, M. 2018. Dozimeters in business safety, İstanbul Aydın Üniversitesi Dergisi, 10 (1), 15-31.

[9] Karataşl1, M. 2018. Radionuclide and heavy metal content in the table olive (Olea europaea 1.)from the Mediterranean region of Turkey, Nuclear Technology \& Radiation Protection, 33,4, 1-7.

[10] Bozkurt, A., Yorulmaz, N., Kam, E., Karahan, G. and Osmanlığlu, A. E. 2007. Assessment of environmental radioactivity for Şanliurfa region of Southeastern Turkey. Radiation Measurements, $42,8,1387-1391$.

[11] http://www.cografya.gen.tr/tr/adiyaman/ (24.01.2019).

[12] Aykut, M., and Taşar, G.E. 2018. Contributions To The Knowledge Of Adephagan Fauna In Adiyaman Province, Turkey (Coleoptera: Dytiscidae, Gyrinidae, Haliplidae And Noteridae),Munis Entomology \& Zoology, 13, 1, 249-255.

[13] http://www.adiyamankulturturizm.gov.tr/TR-61334/genel-bilgiler.html (23.01.2019).

[14] Karadoğan, S., and Tonbul, S. 2013. Geomorphological properties of Adıyaman Basin, The Journal of Academic Social Science, 1,1, 182-217.

[15] KARATAȘLI, M. 2019. Determination of outdoor absorbed gamma dose rates of Kahramanmaraş Province, Turkey, Cumhuriyet University, Cumhuriyet Science Journal. 40 (1), 102-107.

[16] Değerlier, M. 2007. Determination ofEnviromental Natural Radioactivity of Adana and The Annual Effective Dose Equivalent Due to Natural Radiation, Ph.D. Thesis, Department Of Physics Institute Of Natural And Applied Sciences University of Çukurova, Adana

[17] Baykara, O. 2005. The determinations of natural radioactivity in the intersect zone of the North Anatolian Fault and East Anatolian Fault. PhD thesis, Firat University Graduate School of Natural and Applied Science, Physics Department, Elazig, Turkey (in Turkish).

[18] UNSCEAR, 2000. Report of the United Nations Scientific Committee on the Effects of Atomic Radiation, Sources, Effects, and Risks of Ionizing Radiation. United Nations sales publication, New York. United Nations.

[19] Karataşl1, M., Turhan, Ş., Varinlioğlu, A., and Yeğingil, Z. 2016. Natural and fallout radioactivity levels and radiation hazard evaluation in soil samples. Environmental Earth Science, 75, 424, 1-9. 
[20] UNSCEAR 2008. Report of the United Nations Scientific Committee on the Effects of Atomic Radiation, Sources, Effects, and Risks of Ionizing Radiation. United Nations sales publication, New York. United Nations.

[21] Ramasamy V., Sundarrajan M., Paramasivam K., Meenakshisundaram V., and Suresh G., 2013. Assessment of spatial distribution and radiological hazardous nature of radionuclides in high background radiation area, Kerala, India. Applied Radiation Isotopes, 73:21-31.

[22] Taskin, H., Karavus, M., Ay, P., Topuzoglu, A., Hidiroglu, S., and Karahan, G. 2009. Radionuclide concentrations in soil and lifetime cancer risk due to gamma radioactivity in Kirklareli, Turkey. Journal of Environmental Radioactivity, 100,1, 49-53.

[23] NRC,2006. National Academy of Sciences. National Research Council Committee to Assess Health Risks from Exposure to Low Levels of Ionizing Radiation. Report of VII

[24] ICRP, 2007. International Commission on Radiological Protection. Recommendations of the ICRP. ICRP Publication 103. Ann. ICRP 37 (2-4).

[25] UNSCEAR, 2000. United Nations Scientific Committee on the Effect of Atomic Radiation to the General Assembly, Sources, Effects and Risk of Ionizing Radiation, United Nations, New York, USA.

[26] Kapdan, E., Taşkın, H., Kam, E., Osmanlıŏlu, A.E., Karahan, G., and Bozkurt A. 2011. A study of environmental radioactivity measurements for Cankiri. Turkey. Radiation Protection Dosimetry, 150, 3, 398-404.

[27] Kurnaz, A., Kucukomeroglu, B., Damla, N., and Cevik, U. 2011. Radiological maps for Trabzon, Turkey. Journal of Environmental Radioactivity, 102, 4, 393-399.

[28] Kam, E., Yarar, Y., and Bozkurt, A. 2010. A study of background radioactivity level for Tekirdag. Turk Radiat Prot Dosimetry, 138, 40-44.

[29] Kam, E., Bozkurt, A., and Ilgar, R. 2010. A study of background radioactivity level for Canakkale. Turkey. Environmantal Monitoring and Assessment, 168, (1-4), 685- 690.

[30] Kam, E., and Bozkurt, A. 2007. Environmental radioactivity measurements in Kastamonu region of northern Turkey. Applied Radiation and Isotopes, 65, 440-444.

[31] Karahan, G. and Bayulken, A. 2000. Assesment of Gamma Dose Rates Around Istanbul. Journal of Envrionmental Radioactivity, 47, 2, 213-221.

[32] Kapdan, E., Varinlioglu, A., and Karahan, G. 2012. Outdoor radioactivity and health risks in Balikesir, Northwestern Turkey, Radiation Protection Dosimetry, 148, 3, 301-309.

[33] Kapdan, E., Varinlioglu, A. and Karahan, G. 2011. Radioactivity Levels and Health Risks due to Radionuclides in the Soil of Yalova, Northwestern Turkey. International Journal of Environmental Research, 5(4), 837-846.

[34] ICRP, 1990. The International Commission on Radiological Protection, ICRP Publication 60. Recommendations of the International Commission on the Radiological Protection, Pergamon Press Inc., ICRP, USA. 